UDK 595.768.1:582.475(234.422 Zvijezda)

\title{
USING TRAP TREES FOR MONITORING AND CONTROL OF BARK BEETLE PITYOGENES CHALCOGRAPHUS (L.) ON MOUNTAIN ZVIJEZDA
}

Korištenje lovnih stabala za praćenje i suzbijanje potkornjaka Pityogenes chalcographus

\author{
(L.) na planini Zvijezdi
}

Nermin Demirović ${ }^{1}$, Mirza Dautbašić ${ }^{2}$, Kenan Zahirović ${ }^{3}$ i Osman Mujezinović ${ }^{2}$

\begin{abstract}
Bark beetles are the most important pests of the coniferous forests. Although they are considered to be a secondary pest, they are becoming the primary pests that attack healthy trees. One of the important spruce bark beetle is the Pityogenes chalcographus (L.) - a small spruce beetle. The research was conducted in the municipality of Vareš, on three locations: Ponikva, Pobrin Han, Doli. The active period of the bark beetle for development began in the last decade of April. P. chalcographus in the field of research had two generations. For the development of generations it took between 12 and 13 weeks. Weather conditions in the object of research did not allow the completion of the second generation. The activity of the bark beetle ends in midSeptember. When we talk about the characteristics of wood material which prefers small bark beetle of spruce, we can say that he prefers to inhabit thinner parts of trunk with thin and smooth rind. In the object of research for monitoring of population of bark beetle $P$. chalcographus was used trap trees. As a measure to combat the small spruce bark beetles are strongly advised in due time, autumn and winter, remove the dried trees and trees with drilled bark beetles. Maintenance and establishment of forest order to reduce the amount of wood material suitable for the settlement of bark beetles.
\end{abstract}

Key words: spruce, Pityogenes chalcographus (L.), control of the bark beetles, trap trees.

\section{INTRODUCTION - Uvod}

Bark beetles (Coleoptera, Curculionidae) are first-class pests in our conifer forests. They belong to the most important pests of coniferous forests in the Palearctic region (Pfefer, 1995; Christiansen AND BAKKE, 1988). Given to its importance, they are considered the most important fauna. In case of stable forest ecosystems, bark beetles along with other organisms, make constitutive component heterotrophs consumers and then represent no threat to forest stands. In these stands, bark beetles are not primary pests, and can not exceed the critical threshold number. Usually

\footnotetext{
${ }^{1}$ Public enterprise „Sarajevo - šume“ d.o.o. Sarajevo

${ }^{2}$ University of Sarajevo, Faculty of Forestry

${ }^{3}$ Public enterprise "Šumsko-privredno društvo Zeničko-dobojskog kantona" d.o.o. Zavidovići
} 
inhabit trees with reduced vitality, and only in the outbreak (graduation) bark beetles become primary pests.

Economically the most important, and at the same time the most dangerous, insects on spruce are Ips typographus and Pityogenes chalcographus (CHRISTIANSEN AND BAKKE, 1988; WeRmeLinger ET AL., 2012; SCHROEDER, 2013; MONTANO ET AL., 2016). Often, due to the favorable conditions for their colonization and reproduction, they lead in question the survival of entire forest complexes, and the forest estate is being removed from the normal course of commerce. The mass appearance of bark beetles is conditioned by weather conditions and the general physiological condition of the stands (GEORGIJEVIĆ, 1962; GaVRILOVIĆ AND KORPIČ, 1992). Material for colonization of bark beetles are physiologically weakened trees. Especially favorable conditions are found on freshly harvested timber and under conditions where of forest disorganization, where can be found or a lot of suitable material for bark beetle development. Particularly attractive is the harvested wood mass that was affected by the influence of wind and snow during the winter. If damaged trees remain in the forest untreated, they can be attacked by bark beetles during the vegetation, and next year too (GÖTHLIN ET AL., 2000). The attack of bark beetles as a natural process in the forests is partially enlarged due to the negligence of forest hygiene and noncompliance with the regulations on the production of forest wood assortments - the conifers are no longer peeling after regular harvesting. All of this can contribute to an increase in the usual quantities of attacked conifer trees in the stands (HRAŠOVEC ET AL., 2012).

Until the seventies of the last century for control and combat bark beetle was widely used mechanical method called "trap trees". For trap trees according to MiHAJLOVić (2008), some defective and depressed trees should be chosen, as well as those with less technical values. Freshly harvested trees attract bark beetles that are bore to them in order to reproduction. When insects bore in trap tree, then the bark is peeled off and need to be burned. In the case where under bark, bark beetles are at the stage of the larvae and the pupa, it is sufficient to turn only the peeled bark so that the part with the sapwood is turned to the sun. For effective use of this method, it is necessary to place a sufficient number of trap trees and in that way prevent the attack of bark beetles on the living trees. Usually, the number of trap trees being set ranges from 1 to $10 \%$ of the total number of trees that have been dried. Trap trees can attract bark beetles to distances up to $0,8 \mathrm{~km}$ (KRIEGER, 1998).

For timely barking of trap trees, it is necessary to continually perform control to determine the stage in which the bark beetles are. The barking should start as soon as under bark is found development stages of the eggs and larvae. For the first generation of bark beetles it is usually three weeks after a strong attack of the bark beetles, and for the second generation of two weeks. If it is for some reason barking is delayed, bark beetles can attack adjacent unaffected trees. In this case, this method does not give the desired results and helps the spread of the bark beetles, which is one of the main deficiency of the use of trap trees (KovAČEVić, 1951). There are two types of trap trees - fallen and standing. Fallen trap trees are more suitable for use in 
practice. Trap trees are set up in trap trees series to catch the bark beetles of the first and second generations. Trap trees on which the branches are located, in the interior of the stands, are faster dry than trap trees without branches. The reason for this is transpiration of the crown for some time. However, in the sunny parts the situation is reversed. Branches are dried faster and stop transpirating while simultaneously making a certain type of overshadow that loses moisture more slowly. Harvesting of trees should be done before the first insect swarming to keep the tree wet for a certain amount of moisture. This means that the first trap trees should be dropped about 40 days before the first insect swarming. When trap trees are used to suppress of bark beetle Pityogenes chalcographus, it is advisable to choose tree with a thinner bark (FITZE, 1954).

Trap trees should be planted on the edges of the stand where the canopy of trees is not complete so that the trees are half a day in the light and half a day in the shade. The use of trap trees as a measure of the fight against bark beetles is ecologically acceptable.

\section{MATERIAL AND METHODS - Materijal i metode}

The research was conducted on three localities: 1. Pobrin Han (Department 21, Management Unit "Gornja Stavnja" and Department 125, Management Unit "Gornja Trstionica Bukovica"); 2. the locality Ponikva (Department 30 and 61 Management Unit "Gornja Stavnja"); 3. the locality Doli (Department 21 and 25 Management Unit "Gornja Misoča"). On March 20, 2008, 12 trees of the first series were placed in three localities by four trees (Picture 1). The trees belonged to a diameter class of 10 to 80 $\mathrm{cm}$ with differently characterized type of bark. For trap trees, completely healthy and unobtrusive trees with different ribs and thickness of the bark were harvested. A total of 36 trap trees were placed, four trees on each site of the study in three series. On trap trees, data were collected on the invasion of the bark beetles, and the bionomy. Inlet holes on trap trees are recorded on pre-marked surfaces of $4 \mathrm{dm}^{2}(40 \mathrm{~cm} \times 10 \mathrm{~cm})$ (Picture 2). The distance between these surfaces on the tree was $2 \mathrm{~m}$. On each $2^{\text {nd }}$ meter were marked three surfaces of $4 \mathrm{dm}^{2}$, one on the upper side of the trap tree and two on the sides. On each surface, the type of bark was determined: thick coarse ( $>4$ $\mathrm{mm})$, thick smooth $(>4 \mathrm{~mm})$ and thin smooth $(<4 \mathrm{~mm})$ thin. The method of placing the surface on the part of the trap tree located at the top of the crown differed slightly. Due to the smaller number of trees in these parts, the surfaces are located so that one is positioned in front of the other behind the measured spot. The cropping of branches was not carried out, but only those branches that were broken when harvesting the trees. The marking of the surface was done first with a small trigger, so that the dead part of the bark was removed without damaging the sapwood, and then with the waterproof felt pen was marked contour of surface of $4 \mathrm{dm}^{2}$. 

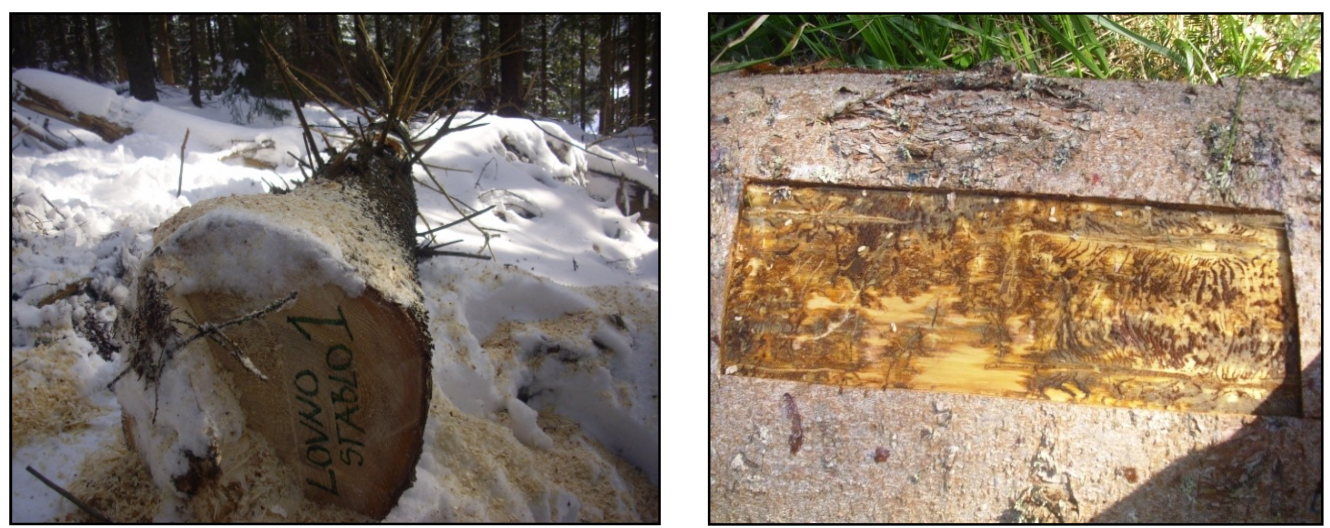

Picture 1 and 2. Harvested trap tree (left), debarking process the marked area (right)

Slike 1 i 2. Oboreno lovno stablo (lijevo), postupak skidanja kore sa označenih površina (desno)

Every ten days was carried out a review of marked areas on trap trees. The observed inlet holes are marked with a waterproof felt pen. Each time was used second color felt pen, all in order to better control the inlet holes. Recording of the inlet holes is done in specially prepared manuals. At the end of the generation, the correction was done by carefully debarking the marked surfaces and comparing the inlet holes with maternal corridor. Based on the average number of inlet holes per $\mathrm{dm}^{2}$, was established the intensity of the attack according to the following scale: $<0,5$ inlet holes $/ \mathrm{dm}^{2}$ - weak intensity, $0,5-1$ inlet holes $/ \mathrm{dm}^{2}$ - medium intensity and $>1$ inlet holes $/ \mathrm{dm}^{2}$ - strong intensity (ŠVETSKA ET AL., 2009). The debarking material removed after drying and was stored, and the remaining bark from trap trees was removed and burnt.

The collected data provide basic information on the density, numeracy and bionomy of $P$. chalcographus. Also, after processing the data, it is determined which type of wood material prefers this bark beetle. Systematized data are processed using standard statistical methods in MS Excel 2007 and SPSS 18 program.

\section{RESULTS - Rezultati istraživanja}

On the basis of the recordings of the inlet holes was determined the stream of inlet holes in trees (Fig. 1) and the development phases of P. chalcographus was shown in Table 1. 


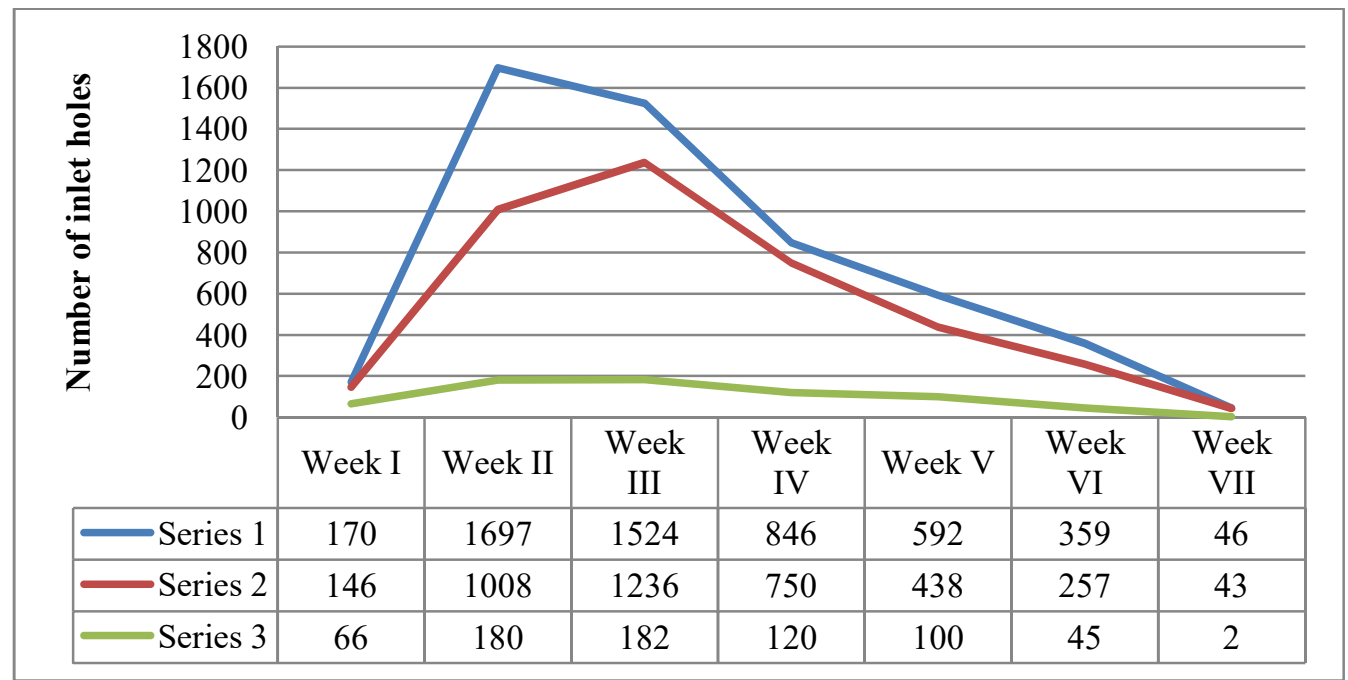

Figure 1. Inlet holes of bark beetles of $P$. chalcographus in trap trees

Grafikon 1. Tok ubušivanja potkornjaka P. chalcographus u lovna stabla

Table 1. Development stages of $P$. chalcographus in object of research

Tabela 1. Razvojne faze potkornjaka $P$. chalcographus u objektu istraživanja

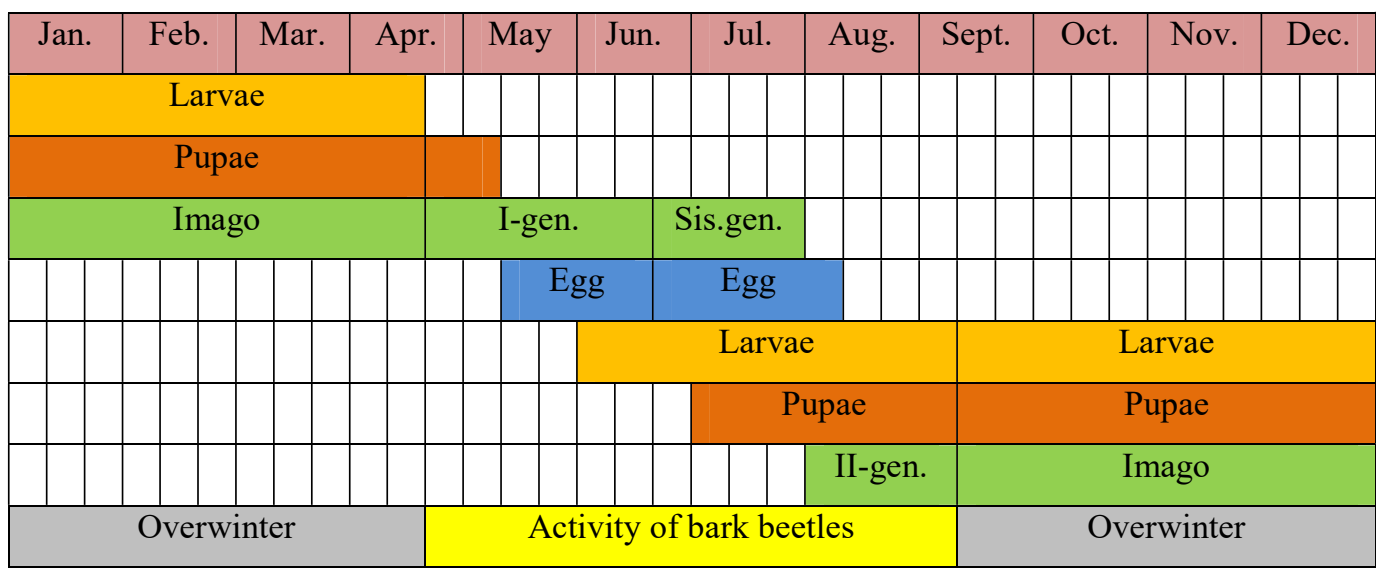

One of the objectives of the research is to determine the thickness of the wood material according to which $P$. chalcographus has affinity. Therefore, when selecting trap trees was taken into account their diameter structure (Table 2). 
Using trap trees for monitoring and control of Bark beetle Pityogenes chalcographus (L.) On mountain Zvijezda

Table 2. Diameter structure of trap trees by trap series

Tabela 2. Debljinska struktura lovnih stabala po lovnim serijama

\begin{tabular}{|c|c|c|c|c|c|}
\hline \multirow{2}{*}{ Trap series } & \multicolumn{4}{|c|}{ Number of trap trees by diameter classes (cm) } & \multirow{2}{*}{ Total } \\
\cline { 2 - 5 } & $10,0-19,9$ & $20,0-29,9$ & $30,0-49,9$ & $50,0-79,9$ & \\
\hline $1^{\text {st }}$ & 3 & 3 & 4 & 2 & 12 \\
\hline $2^{\text {nd }}$ & 3 & 3 & 4 & 2 & 12 \\
\hline $3^{\text {rd }}$ & 3 & 2 & 4 & 3 & 12 \\
\hline Total & 9 & 8 & 12 & 7 & 36 \\
\hline
\end{tabular}

In Table 3 are shown the basic data about inlet holes of $P$. chalcographus by trap series.

Table 3. Review of number of inlet holes of bark beetle $P$. chalcographus by trap series Tabela 3. Pregled broja ubušivanja potkornjaka P. chalcographus po lovnim serijama

\begin{tabular}{|c|c|c|c|c|c|c|}
\hline $\begin{array}{c}\text { Trap } \\
\text { series }\end{array}$ & $\begin{array}{c}\text { Number } \\
\text { of trap } \\
\text { trees }\end{array}$ & $\begin{array}{c}\text { Min. } \\
\text { number of } \\
\text { inlet holes }\end{array}$ & $\begin{array}{c}\text { Max. } \\
\text { number of } \\
\text { inlet holes }\end{array}$ & $\begin{array}{c}\text { Average } \\
\text { number of } \\
\text { inlet holes }\end{array}$ & $\begin{array}{c}\text { Standard } \\
\text { deviation }\end{array}$ & Variance \\
\hline $1^{\text {st }}$ & 12 & 88 & 1073 & 436,2 & 312,1 & 97375,4 \\
\hline $2^{\text {nd }}$ & 12 & 159 & 798 & 323,2 & 190,5 & 36272,9 \\
\hline $3^{\text {rd }}$ & 12 & 11 & 195 & 57,75 & 61,7 & 381,1 \\
\hline
\end{tabular}

For the purpose of determining the significance of the difference in the average number of bark beetles $P$. chalcographus per trap series, the t-test for independent samples was used, and the results are shown in Table 4. 
Table 4. Analysis of significance of the difference in the average number of bark beetles $P$. chalcographus per trap series

Tabela 4. Analiza značajnosti razlika u prosječnom broju ubušivanja potkornjaka $P$. chalcographus po lovnim serijama

\begin{tabular}{|c|c|c|c|c|c|c|}
\hline \multicolumn{7}{|c|}{ t-test for independent samples } \\
\hline & \multicolumn{6}{|c|}{ Trap tree series } \\
\hline & $1^{\text {st }}$ & $2^{\text {nd }}$ & $1^{\text {st }}$ & $3^{\mathrm{rd}}$ & $2^{\text {nd }}$ & $3^{\text {rd }}$ \\
\hline Average & 436,17 & 323,17 & 436,17 & 57,75 & 323,17 & 57,75 \\
\hline Variance & $\begin{array}{c}97375,4 \\
2\end{array}$ & $\begin{array}{c}36272,8 \\
8\end{array}$ & $\begin{array}{c}97375,4 \\
2\end{array}$ & $\begin{array}{c}3801,1 \\
1\end{array}$ & $\begin{array}{c}36272,8 \\
8\end{array}$ & $\begin{array}{c}3801,1 \\
1\end{array}$ \\
\hline Observation & 12 & 12 & 12 & 12 & 12 & 12 \\
\hline Pondered variance & $\begin{array}{l}66824,1 \\
5\end{array}$ & & $\begin{array}{c}50588,2 \\
7\end{array}$ & & $\begin{array}{c}20037,0 \\
0\end{array}$ & \\
\hline $\begin{array}{l}\text { Hypothetical difference of } \\
\text { average }\end{array}$ & 0 & & 0 & & 0 & \\
\hline$d f$ & 22 & & 22 & & 22 & \\
\hline $\mathrm{t}$ - Calculated & 1,071 & & 4,121 & & 4,593 & \\
\hline $\mathrm{P}(\mathrm{T}<=\mathrm{t})$ One side & 0,148 & & 0,000 & & 0,000 & \\
\hline $\mathrm{t}$ - Critic one side & 1,717 & & 1,717 & & 1,717 & \\
\hline $\mathrm{P}(\mathrm{T}<=\mathrm{t})$ Two sided & 0,296 & & 0,000 & & 0,000 & \\
\hline $\mathrm{t}-$ Critic two sided & 2,074 & & 2,074 & & 2,074 & \\
\hline
\end{tabular}

The null hypothesis was set: "There are no statistically significant differences in the average number of inlet holes of bark beetle P. chalcographus in the trees of different trap series." By testing, it was found that there are no significant differences in the average number of inlet holes of bark beetle $P$. chalcographus between the $1^{\text {st }}$ and $2^{\text {nd }}$ trap series. Significant differences in average number of inlet holes were found between $1^{\text {st }}$ and $3^{\text {rd }}$ trap series, and $2^{\text {nd }}$ and $3^{\text {rd }}$ trap series. 


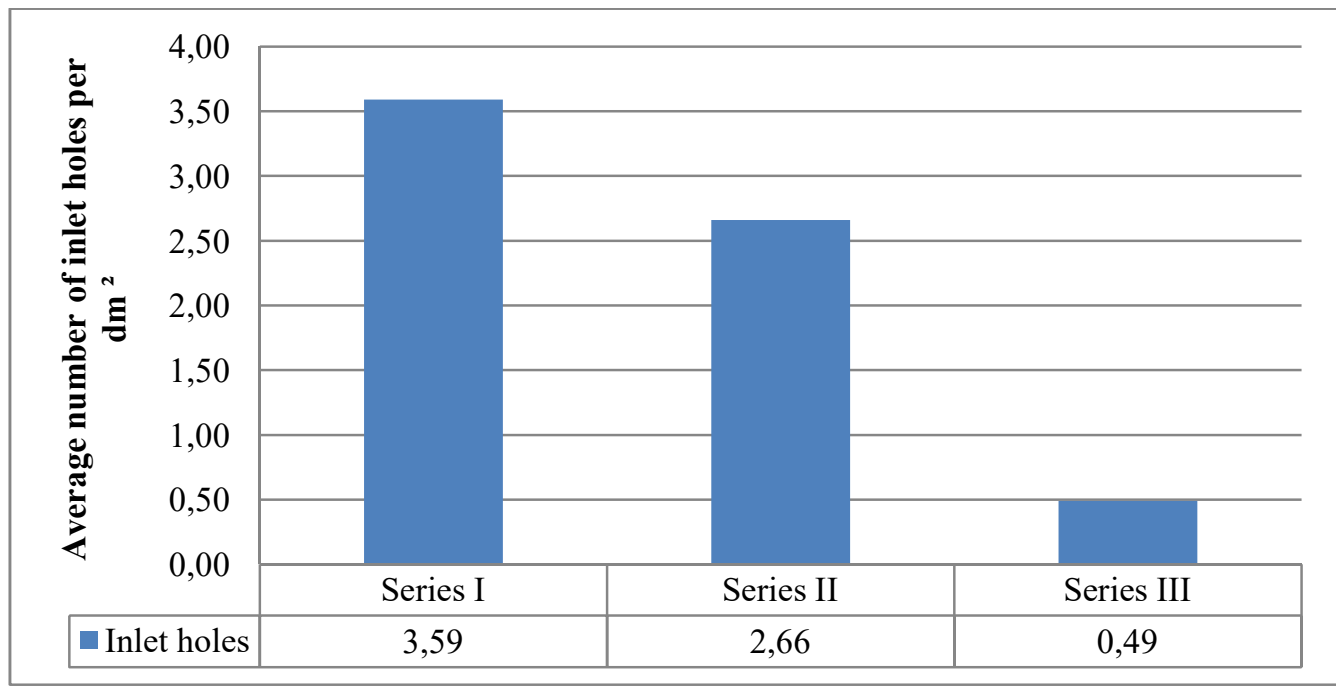

Figure 2. Intensity of attack of bark beetle $P$. chalcographus by trap series Grafikon 2. Intenzitet napada potkornjaka P. chalcographus po lovnim serijama

The strong intensity of the attack of a small spruce bark beetle was recorded on the $1^{\text {st }}$ and $2^{\text {nd }}$ trap series, and weak on the $3^{\text {rd }}$ trap series. Record of inlet holes was done by sections. The length of the section is $2 \mathrm{~m}$ and they are set along from stump to the top of tree, and on each section was measured mean diameter. Based on data of the section diameter and the number of inlet holes, it is tried to determine the thickness of the wood material preferred by the small spruce bark beetle (Table 5). A hi-squares test was used to analyze the significance of the diameter dependence and the number of inlet holes. The null hypothesis was set: "There are no statistically significant differences in the intensity of the attack of a small spruce bark beetle by the thickness of the wood material (section)." 
Table 5. Analysis of the significance of the difference in the intensity of the attack of the P. chalcographus by the thickness of the wood material

Tabela 5. Analiza značajnosti razlika u intenzitetu napada potkornjaka P. chalcographus prema debljini drvnog materijala

\begin{tabular}{|c|c|c|c|c|c|c|}
\hline \multicolumn{7}{|c|}{ Observed frequencies } \\
\hline & & & \multicolumn{3}{|c|}{ Inlet holes } & \multirow[b]{2}{*}{ Total } \\
\hline \multicolumn{2}{|c|}{ Diameter of section } & & Total number & \multicolumn{2}{|c|}{ Expected number } & \\
\hline \multicolumn{2}{|c|}{$\mathrm{I}(<20,0 \mathrm{~cm})$} & & 7259 & \multicolumn{2}{|c|}{2567,25} & 9826,25 \\
\hline \multicolumn{2}{|c|}{ II $(20,0-29,9 \mathrm{~cm})$} & & 2554 & \multicolumn{2}{|c|}{2567,25} & 5121,25 \\
\hline \multicolumn{2}{|c|}{ III $(30,0-39,9 \mathrm{~cm})$} & & 373 & \multicolumn{2}{|c|}{2567,25} & 2940,25 \\
\hline \multicolumn{2}{|c|}{ IV $(>40,0 \mathrm{~cm})$} & & 83 & \multicolumn{2}{|c|}{2567,25} & 2650,25 \\
\hline \multicolumn{2}{|c|}{ Total } & & 10269 & \multicolumn{2}{|c|}{10269} & 20538 \\
\hline \multicolumn{7}{|c|}{ Expected frequencies } \\
\hline & & & \multicolumn{3}{|c|}{ Inlet holes } & \\
\hline \multicolumn{2}{|c|}{ Diameter of section } & & Total number & \multicolumn{2}{|c|}{ Expected number } & Total \\
\hline \multicolumn{2}{|c|}{$\mathrm{I}(<20,0 \mathrm{~cm})$} & & 4913,125 & \multicolumn{2}{|c|}{4913,125} & 9826,25 \\
\hline \multicolumn{2}{|c|}{ II $(20,0-29,9 \mathrm{~cm})$} & & 2560,625 & \multicolumn{2}{|c|}{2560,625} & 5121,25 \\
\hline \multicolumn{2}{|c|}{ III $(30,0-39,9 \mathrm{~cm})$} & & 1470,125 & \multicolumn{2}{|c|}{1470,125} & 2940,25 \\
\hline \multicolumn{2}{|c|}{$\operatorname{IV}(>40,0 \mathrm{~cm})$} & & 1325,125 & \multicolumn{2}{|c|}{1325,125} & 2650,25 \\
\hline \multicolumn{2}{|c|}{ Total } & & 10269 & \multicolumn{2}{|c|}{10269} & 20538 \\
\hline \multicolumn{3}{|c|}{ Calculations (fo-fe) } & $\mathrm{Ca}$ & ulations (fo-fe) & & \\
\hline & Inl & ioles & & Inl & hole & \\
\hline $\begin{array}{c}\text { Diameter of } \\
\text { section }\end{array}$ & $\begin{array}{c}\text { Total } \\
\text { number }\end{array}$ & $\begin{array}{c}\text { Expected } \\
\text { number }\end{array}$ & $\begin{array}{c}\text { Diameter of } \\
\text { section }\end{array}$ & $\begin{array}{c}\text { Total } \\
\text { number }\end{array}$ & & $\begin{array}{l}\text { xpected } \\
\text { number }\end{array}$ \\
\hline $\mathrm{I}(<20,0 \mathrm{~cm})$ & 2345,9 & $-2345,9$ & $\mathrm{I}(<20,0 \mathrm{~cm}$ & 1120,09 & & 1120,09 \\
\hline $\begin{array}{c}\text { II }(20,0-29,9 \\
\mathrm{cm})\end{array}$ & $-6,6$ & 6,6 & $\begin{array}{c}\text { II }(20,0-29, \\
\mathrm{cm})\end{array}$ & 0,02 & & 0,02 \\
\hline $\begin{array}{c}\text { III }(30,0-39,9 \\
\mathrm{cm})\end{array}$ & $-1097,1$ & 1097,1 & $\begin{array}{c}\text { III }(30,0-39 \\
\mathrm{cm})\end{array}$ & 818,76 & & 818,76 \\
\hline $\operatorname{IV}(>40,0 \mathrm{~cm})$ & $-1242,1$ & 1242,1 & IV $(>40,0 \mathrm{~cm}$ & 1164,32 & & 1164,32 \\
\hline & Data & & & Results & & \\
\hline Signific & & 0,05 & Critic & I value & & 7,814728 \\
\hline Number $\mathrm{o}$ & ows & 4 & Statisti & al $\lambda^{2}$ test & & 6206,382 \\
\hline Number of & lumns & 2 & & lue & & 0,000 \\
\hline Degrees of & edom & 3 & The $\mathrm{n}$ & 11 hypothesis is & t & \\
\hline
\end{tabular}


The analysis shows that there is a difference in the intensity of the attack the small spruce bark beetle on wood materials of different thicknesses.

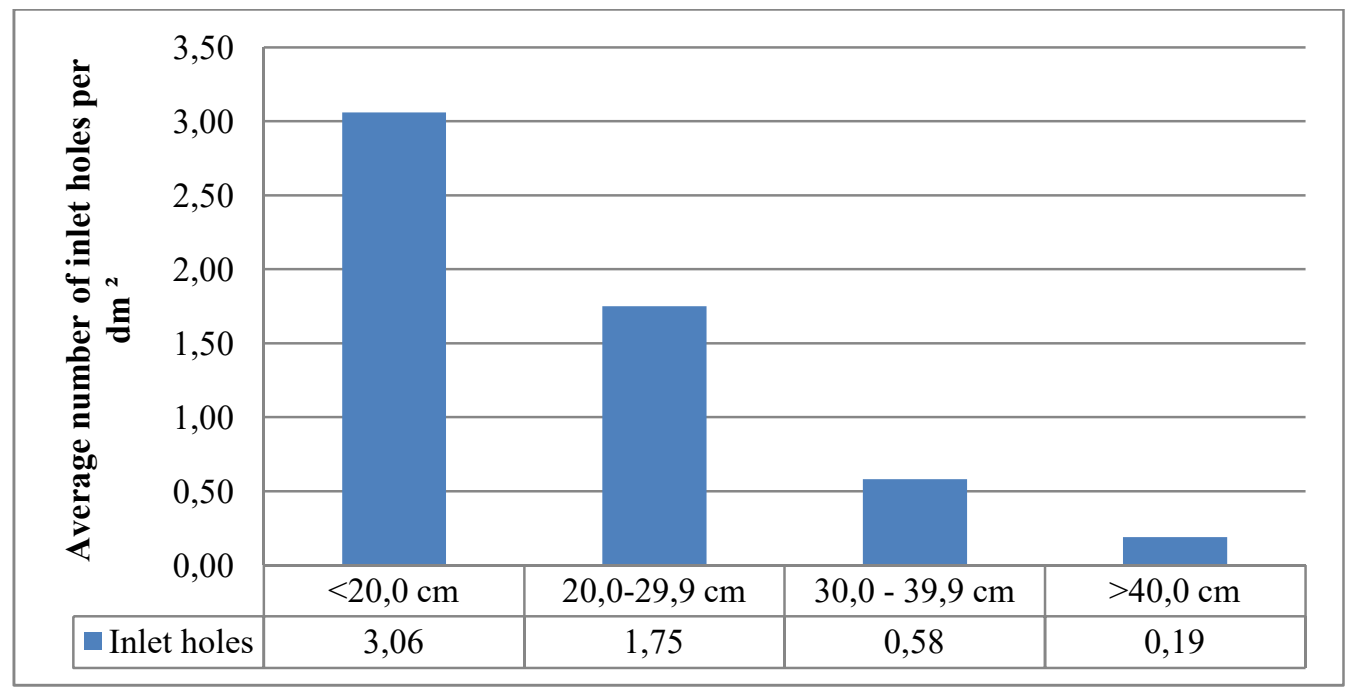

Figure 3. Intensity of attack of bark beetle $P$. chalcographus by the thickness of the wood material

Grafikon 3. Intenzitet napada potkornjaka P. chalcographus po debljini drvnog materijala

Strong intensity of attack of the small spruce bark beetle was on wood material thinner than $30 \mathrm{~cm}$, medium-strong to the wood material $30-40 \mathrm{~cm}$ and weak intensity on wood materials over $40 \mathrm{~cm}$. In order to determine the roughness and thickness of the bark, according to which $P$. chalcographus has affinity, it was conducted bark typing on trap trees. All bark thicknesses more then $4 \mathrm{~mm}$ were considered to be thick, and all bar thinner then $4 \mathrm{~mm}$ was thin. So we finally had three types of bark: thick barky $(>4 \mathrm{~mm})$, thick smooth $(>4 \mathrm{~mm})$ and thin smooth $(<4 \mathrm{~mm})$. Table 6 shows the analysis of the significance of the difference in the intensity of the attack of a small spruce bark beetle by the type of bark. The null hypothesis was set: "There are no statistically significant differences in the intensity of the attack of a small spruce bark beetle by a different type of bark." For the analysis of significance in the intensity of the attack of a small spruce bark beetle, a hi-squared test was used. 
Table 6. Analysis of significance in the intensity of the attack of bark beetle P.chalcographus by a different type of bark

Tabela 6. Analiza značajnosti razlika u intenzitetu napada potkornjaka P.chalcographus prema tipu kore

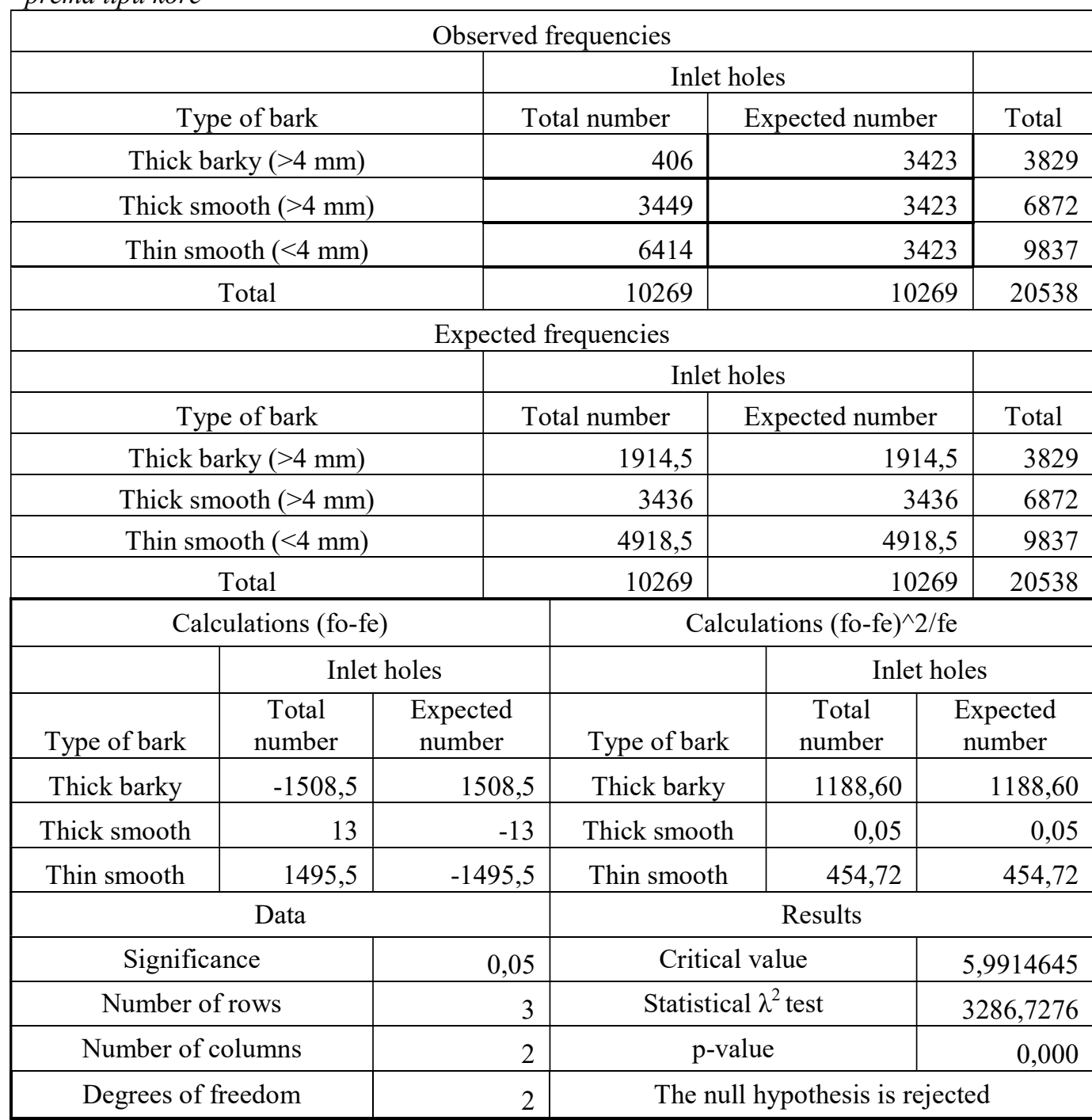

The results of the analysis show that there is a significant difference in the intensity of the attack of a small spruce bark beetle by type of bark. 


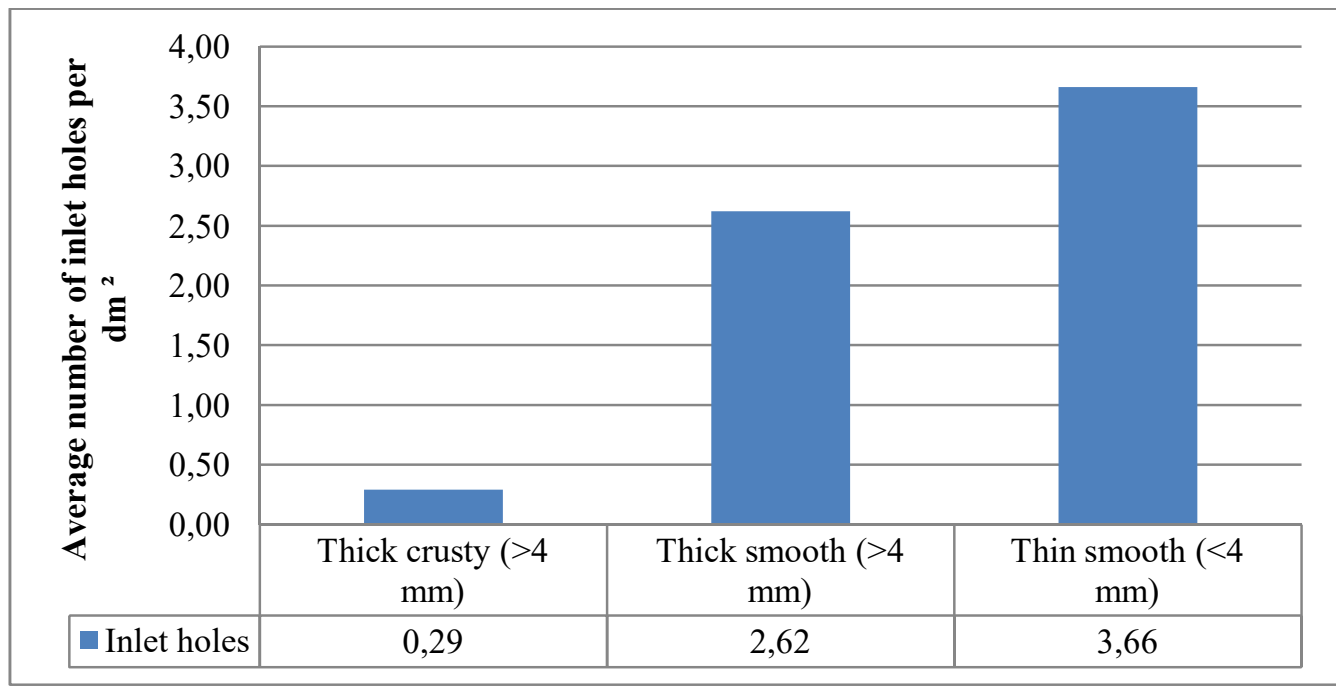

Graphic 4. Intensity of attack of bark beetle $P$. chalcographus by type of bark Grafikon 4. Intenzitet napada potkornjaka P. chalcographus po tipu kore

The strong intensity of the attack of a small spruce bark beetle was established on a thin smooth and thick smooth bark, while on a thick barky bark was a low intensity of attack.

\section{DISCUSSION - Diskusija}

After the first spring swarming for the first generation, on June 20, it was found increased number of made inlet holes on the trap trees for the generating a sister generation (Figure 1, table 1). The second generation was cut off in mid-September due to cooling and less favorable weather conditions. Based on the seasonal catch of a small spruce bark beetle we can say that in 2008 , in the object of the research was a medium intensity of attack. Under our conditions, the small spruce bark beetle has a double generation (GAVRILOVIĆ AND KORPIČ, 1992; JURC ET AL., 2006; B ZUBRIK ET AL., 2008; BERTHAU ET AL., 2013). At higher altitudes this beetle can only have one generation. In the field of research, according to our results, in 2008 the small spruce bark beetle had one pure and one sister generation. Second generation of beetles was interrupted due to unfavorable weather conditions that occurred in the research facility.

In the field of research, 36 trap trees were placed in three trap series. Each trap series had 12 trees. In each trap series, trees were represented with their breast diameter classes in the following thicknesses: 10,0-19,9 cm, 20,0-29,9 cm, 30,0-49,9 $\mathrm{cm}$ and 50,0-79,9 $\mathrm{cm}$ (Table 2). The smallest number of inlet holes was recorded on the tree belonging to the $3^{\text {rd }}$ trap series, and the largest number of inlet holes on the tree from the $1^{\text {st }}$ trap series. The highest average number of inlet holes is in the $1^{\text {st }}$ trap 
series and is 436,2 per tree. The average number of inlet holes in the $2^{\text {nd }}$ trap series is 323,2 and in $3^{\text {rd }} 57,8$ per tree (Table 3 ). The test showed that there were no significant differences in the average number of inlet holes of a small spruce bark beetle between $1^{\text {st }}$ trap series and $2^{\text {nd }}$ trap series. Significant differences in average number of inlet holes were determined between $1^{\text {st }}$ trap series and $3^{\text {rd }}$ trap series, and between $2^{\text {nd }}$ trap series and $3^{\text {rd }}$ trap series (Table 4). Such results are explained by the fact that the bark beetle $P$. chalcographus had one pure and one sister generation and inlet holes was found on the $1^{\text {st }}$ and $2^{\text {nd }}$ trap series. The number of inlet holes in the $1^{\text {st }}$ trap series was the largest and amounted to 3,59 inlet holes $/ \mathrm{dm}^{2}$; the intensity dropped in the following trap series (Figure 2). According to the number of inlet holes per $\mathrm{dm}^{2}$, we can say that on the trees of $1^{\text {st }}$ and $2^{\text {nd }}$ trap series was a strong intensity of attack, while on the $3^{\text {rd }}$ trap series was weak.

One of the aims of this study was to determine of which wood material, in terms of thickness, P. chalcographus has an affinity. For that purpose, the trap trees are divided into sections with a length of $2 \mathrm{~m}$, and on each section is measured mean diameter. All sections are divided into four categories of wood mass based on the average diameter: $<20,0 \mathrm{~cm}, 20,0-29,9 \mathrm{~cm}, 30,0-39,9 \mathrm{~cm}$ and $>40,0 \mathrm{~cm}$. The analysis found that there is a difference in the intensity of the attack of small spruce bark beetle on wood material of different thicknesses categories (Table 5). The intensity of small spruce bark beetle is the largest on wood material less than $20 \mathrm{~cm}$ thick and it is 3,06 inlet holes $/ \mathrm{dm}^{2}$. The intensity of the small spruce bark beetle decreases with the increase of the diameter of the wood material, and on the wood material with a thickness more then $40 \mathrm{~cm}$, it was found 0,19 inlet holes $/ \mathrm{dm}^{2}$ and it is evaluated as weak intensity of attack (Figure 3). According to DAUTBAŠić AND ČABARAVDić (2001), older trees in our conditions are attacked by bark beetle I. typographus, while the younger are attacked by bark beetle $P$. chalcographus. We can conclude that the small spruce bark beetle has a higher affinity for the thin trees and thinner wood material.

The difference in the intensity of the attack of $P$. chalcographus against a different bark type (Table 6) was also determined. For this purpose, on the analyzed parts of the tree, bark typing was performed. Each type of bark is characterized by a certain appearance of the surface (rough, smooth) and by thickness. For the purposes of this paper, a total of three types of barks are defined: thick rough $(>4 \mathrm{~mm})$, thick smooth $(>4 \mathrm{~mm})$ and thin smooth $(<4 \mathrm{~mm})$. The results of the analysis showed that there is a difference in the intensity of attack of the small spruce bark beetle according to the type of bark. The intensity was strong in the case of the "thin smooth" and "thick smooth" bark, and the low intensity was related to the type of "thick rough" bark (Figure 4). The type of "thin smooth" bark is mainly associated with thin wood material and younger trees, so we can say that these are precisely the characteristics of a tree and a bark that is preferred by small spruce bark beetle (ZAHIROVIĆ ET AL., 2016). According to MEŠić ET AL. (2010) and GRUNWALD (1986), bark beetle I. typographus most likely attacks parts of the tree with a bark thickness of about $5 \mathrm{~mm}$. In biological terms, there is a great resemblance to the six-footer of the dead-end of the bottom and the scribble scribe. The basic difference is in the micron that they choose $P$. 
chalcographus chooses the thinner parts of the trunk of the spruce, and I. typographus vice versa.

\section{CONCLUSIONS - Zaključci}

Spruce in European countries is considered the most important conifer species. In Bosnia and Herzegovina, it is behind the fir and beech significance, and makes $1 / 3$ of all our coniferous forests. Bark beetles are among the most significant pests of coniferous forests. In stable forest ecosystems they represent secondary pests. When the stability of forest ecosystems is disturbed, and gradation of bark beetle occurs, they become primary pests. High temperatures, which are the consequence warm summers, have a negative effect on the forest ecosystem, and positively to the gradation of bark beetles. Based on our research we can make the following conclusions:

- P. chalcographus is one the most important bark beetles on the spruce. He most often comes in gradation with the I. typographus.

- Knowing the characteristics of a small spruce bark beetle is crucial for the application of adequate control measures and the fight against gradation.

- P. chalcographus in the object of research had one pure and one sister generation, and between 12 and 13 weeks was needed for the development of the one generation.

- Weather conditions in the research object did not allow to complete of the second generation.

- The activity of this bark beetle starts in the last decade of April and ends in mid-September. From mid-September to the last decade of April of next year, bark beetles overwinter.

- When we talk about the characteristics of wood material that prefers a small bark beetle, we can say that the most desirable wood material is thin trunk part with thin and smooth bark.

- As a measure of the fight against small spruce bark beetle it is certainly recommended timely, autumn and winter, removing of infested trees and trees with inlet holes. Establishment of forest order to reduce the amount of wood material suitable for settlement of bark beetles. 


\section{REFERENCES - Literatura}

Berthau, C., Schuler, H., Arthofer, W., Avtzis, D. N., Mayer, F., Krumböck, S., Moodley, Y., Stauffer, C. (2013): Divergent evolutionary histories of two sympatric spruce bark beetle species. Molecular Ecology 22, 3318-3332.

Christiansen, E., BAKKE, A. (1988): The spruce bark beetle of Euroasia. In: Dynamics of forest insect population: Patterns, Causes, Implications, by Berryman, Alan, A., Plenum Press, New York and London, str. 479-503.

DAUTBAŠić, M. I ČABARAVDić, A. (2001): Upotreba agregacionih feromona za kontrolu i suzbijanje potkornjaka (Scolitidae) smrče u Bosni i Hercegovini. Radovi Šumarskog fakulteta u Sarajevu, No.1, str. 19-33.

FiTZE, K. (1954): Potkornjaci naših četinara, Institut za naučna šumarska istraživanja NR Bosne i Hercegovine, sveska br.3, Sarajevo.

GAVRiLović, D. I KoRPič, M. (1992): Primjena agregacionih feromona za kontrolu i suzbijanje potkornjaka i drvenara u Bosni i Hercegovini. Glasnik Šumarskog fakulteta Univerziteta u Beogradu. No. 74, str. 89-95.

GeORGiJević, E. (1962): O uticaju nadmorske visine i ekspozicije na pojavu Ips typographus L. Radovi šumarskog fakulteta i instituta za šumarstvo u Sarajevu, br.7.

Göthlin, E., Schroeder, L.M., LindelöW, A. (2000): Attacks by Ips typographus and Pityogenes chalcographus on windthrown spruces (Picea abies) during two years fllowing a strom fellings. Scandinavian Journal of Forest Research 15 str. 542549.

GRUNWALD, M. (1986): Ecological segregation of bark beetles (Coleoptera, Scolytidae) of spruce. J. Appl. Entomol. 101, str. 176-187.

Hrašovec, B., KRuŠić, I., Šilić, T., Franjević, M. (2012): Multiyear bark beetle population outbreak in the Northern Velebit nacional park and surrounding forests-menagment strategis and their implications on outbreak dynamics. 3rd European Congress of Conservation Biology, Glasgow, 28 August-1 September 2012, poster. P17.6.

JuRc, M., Perko, M., Džeroski, S., DemĐar, D., Hrašovec, B. (2006): Spruce bark beetles (Ips typographus, Pityogenes chalcographus, Col.: Scolytidae) in the Dinaric mountain forests of Slovenia: Monitoring and modeling ecological modelling 194. str. 219-226

KovAČEVić, Ž. (1951): Lovna stabla i suzbijanje potkornjaka kemijskim sredstvima. Šumarski list br. 1-2, str. 92-93.

KRIEGER, C. (1998): An overview of Bark beetle control methodologies. P.E.I. Department of Agriculture and Forestry, Forestry Division. str. $1-8$.

MEŠić, H., DaUtBAŠić, M., MuJeZinović, O. (2010): Intenzitet napada smrčinog pisara (Ips typographus L.) na lovnim stablima smrče. Naše šume, br. 28-29, str. 11-16. 
MiHAJLović, LJ. (2008): Šumarska entomologija. Šumarski fakultet Univerziteta u beogradu, Beograd.

B Montano, V., Bertheau, C., Doležal, P., Krumböck, S., Okruohlik, J., Stauffer, C., Moodley, Y. (2016): How different management strategies affect Ips typographus L. dispersal. Forest Ecology and Management. 360, 195-204.

Pfefer, A. (1995): Zentral und westpaläarktische Borken und Kernkäfer, (Coleoptera: Scolytidae, Platypodidae). Pro Entomologia, Naturhistorisches Museum Basel, Basel.

SCHROEDER, L.M. (2013): Monitoring of Ips typographus and Pityogenes chalcographus: influence of trapping site and surounding landscape on catches. Agricultural and Forest Entomology. 15, 113-119.

ŠVEstKA, M., Filipović, Ž., KUBAČ, M. (2009): Prijedlog mjera zaštite šuma protiv potkornjaka na smrči u Bosni i Hercegovini. Czech Republic, Development cooperation.

Wermelinger, B., Epper, C., Kenis, M., Ghosh, S., Holdenrieder, O. (2012): Emergence patterns of univoltine and bivoltine Ips typographus (L.) populations and associated natural enemies. Journal of Applied Entomology. 136(3), 212224.

ZahiRović, K., DautBašić, M., MuJezinović, O. (2016): Analiza učinkovitosti feromonskih pripravaka i klopki na području gospodarske jedinice „Gornja Stavnja“ u 2015. godini. UŠIT FBIH. Naše šume br. 42-43. str. 5 - 13.

ZÚBRik, M., Rašı, R., Vakula, J., Varínsky, J., Nikolov, C., NovotnÝ, J. (2008): Bark beetle (Ips typographus L., Pityogenes chalcographus L., Col.: Scolytidae) pheromone traps spatial distribution optimisation in central Slovakian mountains. Lesn. Čas. - Forestry Journal, 54(3): 235 - 248. 


\section{SAŽETAK}

Potkornjaci su najvažnije štetočine četinarskih šuma. Iako se ubrajaju u sekundarne štetnike, u prenamnoženju postaju primarni štetnici, te napadaju zdrava stabla. Jedan od važnijih smrčinih potkornjaka je $P$. chalcographus (L.) - mali smrčin potkornjak. Istraživanje je provedeno na području općine Vareš, na tri lokaliteta: Ponikva, Pobrin Han, Doli. Aktivni period ovog potkornjaka započinje u zadnjoj dekadi aprila. $P$. chalcographus na području objekta istraživanja imao je jednu čistu i jednu sestrinsku generaciju, a za razvoj generacije bilo je potrebno između 12 i 13 sedmica. Vremenski uslovi u objektu istraživanja nisu dozvoljavali završetak druge generacije. Aktivnost ovog potkornjaka počinje u zadnjoj dekadi aprila, a završava polovinom septembra. Od polovine septembra do zadnje dekade aprila naredne godine, potkornjaci su u fazi prezimljavanja. Kada govorimo o karakteristikama drvnog materijala koji preferira mali smrčin potkornjak, možemo reći da najradije naseljava tanje partije debla sa tankom i glatkom korom. Kao mjere borbe protiv malog smrčinog potkornjaka svakako se preporučuje pravovremeno, jesenje i zimsko, uklanjanje osušenih stabala i stabala u koje su se ubušili potkornjaci.

Corresponding author: Nermin Demirović; Public enterprise „Sarajevo - šume“ d.o.o. Sarajevo,Titova 7, 71000 Sarajevo,Bosna\&Herzegovina; e-mail: ner_alma@yahoo.com 